\title{
THE ANTIOXIDANT AND ANTIGENOTOXIC POTENTIAL OF PELTIGERA CANINA AND UMBILICARIA NYLANDERIANA BASED ON THEIR PHENOLIC PROFILE
}

\author{
BUGRAHAN EMSEN * \\ Department of Biology, Kamil Özdă̆ Faculty of Science, Karamanoğlu Mehmetbey University, Karaman, Turkey
}

*corresponding author: bugrahanemsen@gmail.com

Manuscript received: October 2018

\begin{abstract}
The present study aimed to assess the biological effects of methanol and water extracts obtained from Peltigera canina and Umbilicaria nylanderiana on human peripheral lymphocytes. Chromosome aberration and micronucleus tests evaluated genotoxicity levels of the extracts on the cells. In both tests, it was determined that the treatments at concentrations of $1-50$ $\mathrm{mg} / \mathrm{L}$ did not significantly increase genotoxicity. When investigating the total oxidative stress (TOS) levels of the cells exposed to the tested extracts, it was revealed that water extracts decreased TOS in the cells. In order to determine the antioxidant capacities of the extracts, DPPH radical scavenging, metal chelating, reducing power activities and besides, total antioxidant capacity in the cells were measured. Concentration-dependent increases were observed for each antioxidant activity. In addition, there were detected the main phenolic compounds in the extracts by an HPLC method. Consequently, it was revealed that lichen-derived extracts are worth investigating as possible antioxidative agents.
\end{abstract}

\section{Rezumat}

Studiul prezintă efectele biologice ale extractelor apoase și metanolice ale speciilor Peltigera canina și Umbilicaria nylanderiana asupra limfocitelor umane periferice. Mutațiile cromozomiale și testele realizate pe micronuclei au demonstrat nivelul de genotoxicitate celulară. În ambele teste, concentrații cuprinse între 1 și $50 \mathrm{mg} / \mathrm{L}$ nu au prezentat efecte semnificative asupra genotoxicității. În ceea ce privește nivelul stresului oxidativ total (TOS), extractele apoase au scăzut TOS în celule. Au fost determinate activitatea de chelatare a radicalilor liberi și a metalelor, activitatea reducătoare şi capacitatea totală antioxidantă. De asemenea, a fost determinat conținutul fenolic printr-o metodă HPLC. În consecinţă, extractele pe bază de licheni prezintă un interes deosebit pentru potențialul lor antioxidant remarcabil.

Keywords: antioxidant, cytotoxic, genotoxic, lichen, Peltigera canina, Umbilicaria nylanderiana

\section{Introduction}

All multicellular organisms try to protect themselves against harmful microorganisms that can cause disease. Immunity describes the reaction and response of an organism to an agent that can cause all kinds of diseases such as bacteria, viruses, fungi [23]. Lymphocytes are essential cells of the acquired immune system. For this reason, protection of lymphocytes is of great importance for human health [14].

Free radicals that cause oxidative stress in the human body are important elements that negatively affect the immune system. Reactive oxygen and nitrogeninduced oxidative stress have been demonstrated to play a role in a variety of inflammatory and degenerative diseases such as cancer, cataracts, ageing, rheumatoid arthritis and diabetes [4]. The living metabolism that has an established balance between endogenous and exogenous antioxidants undergoes oxidative stress in some conditions. In this context, when occasionally endogenous antioxidants such as catalase, superoxide dismutase, melatonin, uric acid and bilirubin are inadequate, supplementation of exogenous antioxidants may prevent the formation of oxidative stress [18]. Exogenous antioxidants are mostly molecules that can be taken from food or some preparations and usually support the antioxidant system directly or indirectly [25]. Phenolic compounds are the most important among the antioxidant substances found in plant extracts identified as biological materials. Plant-derived antioxidants especially phenols function as free radical scavengers, peroxide scavengers, enzyme inhibitors and synergists [12]. They have positive effects on health by preventing the harmful effects of free radicals, low-density lipoproteins and lipoprotein oxidation [1].

Lichens are among the sources of natural antioxidant substances [6]. They are morphological and physiological associations of fungi brought together by algae. In the lichens, fungi use algae as a carbon source for survival, growth and reproduction. Algae take the mineral, water for photosynthesis from the fungi and are protected by the fungi against adverse conditions such as high temperature, harmful rays, and high humidity [2]. The lichens have long been used as traditional medicinal 
FARMACIA, 2019, Vol. 67, 5

products in many countries. There is much evidence that they are used as a decoction or infusion in the treatment of various diseases [7]. Scientists have also carried out numerous studies in order to demonstrate the protective properties of the lichens by the antioxidant components found in their structures [19]. However, to the best of our knowledge, no adequate information is available regarding the biological activities of Peltigera canina (L.) Willd. and Umbilicaria nylanderiana (Zahlbr.) H. Magn. on human peripheral lymphocytes (HPLs). Therefore, this study aimed to investigate the antioxidant, oxidative, genotoxic and cytotoxic capacities of methanol and water extracts obtained from $P$. canina and U. nylanderiana in HPLs and detect the main phenolic compounds of the tested extracts by high-performance liquid chromatography (HPLC) method.

\section{Materials and Methods}

\section{Materials}

Collection and identification of the lichen samples The samples were collected from Eastern Anatolian region of Turkey $\left(40^{\circ} 35^{\prime} \mathrm{N}-41^{\circ} 49^{\prime} \mathrm{E}\right)$. Necessary morphological and ecological characteristics of the samples were recorded and they were photographed in their natural habitats. After collecting the materials, they were exposed to a dry atmosphere in room conditions. Lichen herbaria were obtained and kept for the records. Comparing the obtained macroscopic and microscopic data with literature [20, 28], they were identified as $P$. canina (KKEF-803) and $U$. nylanderiana (KKEF-804). Voucher specimens are kept in the herbarium of Faculty of Pharmacy, Van Yüzüncü Y1l University, Van, Turkey.

Preparation of the extracts

$20 \mathrm{~g}$ of the lichen samples were dried for 7 days under room conditions and powdered under liquid nitrogen. Then, bioactive ingredients were extracted by $250 \mathrm{~mL}$ of methanol and water solvent systems using a Soxhlet extraction apparatus throughout 2 days. After extraction, solvents were evaporated with a rotary evaporator (IKA, Staufen, Germany) under vacuum to dryness and lyophilized to get ultra-dry powders that were solubilized with the minimum amount of sterile distilled water. While methanol (PME) and water (PWE) extracts isolated from $P$. canina yielded $11.87 \%$ and $13.64 \%(\mathrm{w} / \mathrm{w})$ of lichens substances, respectively, methanol (UME) and water (UWE) extracts of $U$. nylanderiana were obtained with yields of $11.94 \%$ and $12.45 \%$ (w/w), respectively. The stock solutions were prepared with distilled water. Identification and quantification of main phenolic compounds by HPLC

The method described by Rodríguez-Delgado et al. [22] was used to separate the phenolic compounds by HPLC. The samples taken after the extraction were centrifuged at $15000 \mathrm{rpm}$ for $15 \mathrm{~min}$. The supernatant was filtered through a $0.45 \mu \mathrm{m}$ Millipore filter and collected in the vials. The vials were placed in HPLC autosamplers. Chromatographic separation was carried out on an Agilent 1100 HPLC system using a diode array detector and a $250 \times 4.6 \mathrm{~mm}, 4 \mu \mathrm{m}$ octadecyl-silica column. Methanol:acetic acid:water (10:2:88) and methanol:acetic acid:water (90:2:8) solvents were used as mobile phase. HPLC conditions for the separation of phenolic compounds were set at 254 and $280 \mathrm{~nm}$ wavelength. The flow rate and injection volume were determined: $1 \mathrm{~mL} / \mathrm{min}$ and $10 \mu \mathrm{L}$, respectively. Finally, eleven phenolic compounds (chlorogenic acid, p-coumaric acid, q-coumaric acid, ferulic acid, gallic acid, phlorodizin, protocatechuic acid, resveratrol, rutin, syringic acid and valinic) in the extracts were detected.

\section{Blood samples}

Heparinised blood samples were collected from healthy individuals without any disease or active infection. The present study was performed with the approval of the Ethics Committee of the Faculty of Health Sciences of Karamanoğlu Mehmetbey University. Total antioxidant capacity (TAC) assay

TAC analysis was performed in plasma samples obtained from heparinised blood cultures for $2 \mathrm{~h}$ and a commercially available kit (Rel Assay Diagnostics, Gaziantep, Turkey) was used for this purpose, in order to determine the antioxidant levels of samples by inhibiting the formation of a free radical, 2,2'-azinobis (3-ethylbenzothiazoline-6-sulfonic acid) (ABTS) compound.

The cells were incubated for $24 \mathrm{~h}$. The applications of standard, reagent 1 and reagent 2 solutions were completed in the wells of the trial plate. Spectrophotometric readings were performed at $660 \mathrm{~nm}$. The positive control ( control $^{+}$) was ascorbic acid (Sigma-Aldrich, Darmstadt, Germany at $4 \times 10^{-7} \mathrm{M}$ ). Total oxidative stress (TOS) assay

TOS analysis was performed in plasma samples obtained from heparinised blood cultures for $2 \mathrm{~h}$ and a commercially available kit (Rel Assay Diagnostics, Gaziantep, Turkey) was used. The assay implies that complexes with ferric ion are oxidized to ferrous ion by oxidants presented in the sample. The oxidation reaction is carried out with strengthening molecules in the reaction medium. Ferrous ions form a coloured structure with the chromogen in the acidic environment. The colour intensity measured spectrophotometrically is related to the total amount of oxidant molecules in the sample.

The cells were incubated for $24 \mathrm{~h}$. The applications of standard, reagent 1 and reagent 2 solutions were completed in the wells of the trial plate. Spectrophotometric readings were performed at $530 \mathrm{~nm}$. $\mathrm{Control}^{+}$was hydrogen peroxide $\left(\mathrm{H}_{2} \mathrm{O}_{2}\right)$ (SigmaAldrich, Darmstadt, Germany at $5 \times 10^{-4} \mathrm{M}$ ). 
FARMACIA, 2019, Vol. 67, 5

2,2-diphenyl-1-picrylhydrazyl (DPPH) radical scavenging activity

Free radical scavenging activities of the extracts were determined by monitoring DPPH reduction. Gallic acid $(0.01-0.5 \mathrm{mM})$ was used as standard antioxidant molecule and in order to determine the radical scavenging activities, $20 \mu \mathrm{L}$ of various concentrations of standard or extracts were mixed with $180 \mu \mathrm{L}$ of DPPH solution ( $0.06 \mathrm{mM}$ in methanol) and incubated for $1 \mathrm{~h}$ at dark in microtiter plates. Blank measurements without standard or extracts were also performed. After reading the absorbance at $517 \mathrm{~nm}$, the reduction of the DPPH radical was determined as percent discoloration of DPPH which was calculated according to the following formula:

\section{Radical Scavenging Activity (RSA) $(\%)=(\mathrm{DPPH}$ absorbance-DPPH and extract absorbance)/(DPPH absorbance) $\times 100$}

The extract concentrations providing 50\% inhibition $\left(\mathrm{IC}_{50}\right)$ were calculated from extract amount that was used for the comparison of different extracts of tested lichens.

Metal chelating activity

The chelating abilities of the extracts were determined using ethylenediaminetetraacetic acid (EDTA) as a standard chelating agent. Different concentrations of extracts $(1,5,10,25,50$ and $100 \mathrm{mg} / \mathrm{L})$ and standard (0.1 - $5 \mathrm{mM})$ were added to microplate wells $(50 \mu \mathrm{L})$ and mixed with $10 \mu \mathrm{L}$ ferrozine ( $5 \mathrm{mM}$ ), $5 \mu \mathrm{L}$ iron(II) chloride $(2 \mathrm{mM})$ and $185 \mu \mathrm{L}$ absolute methanol. After incubation for $10 \mathrm{~min}$ at room temperature, absorbances were read at $562 \mathrm{~nm}$ and $\mathrm{IC}_{50}$ values were calculated.

\section{Reducing power activity}

The reducing powers of the extracts were determined with an adaptation to microplate measurement. Gallic acid $(0.01-0.1 \mathrm{mM})$ was used as standard antioxidant. In this method, various concentrations of $50 \mu \mathrm{L}$ lichen extracts $(1,5,10,25,50$ and $100 \mathrm{mg} / \mathrm{L})$ were mixed with $75 \mu \mathrm{L}$ phosphate buffer $(0.2 \mathrm{M} \mathrm{pH}$ : 6.6) and $75 \mu \mathrm{L}$ potassium ferricyanide $(1 \% \mathrm{w} / \mathrm{v})$ in a total volume of $200 \mu \mathrm{L}$ and incubated at $50^{\circ} \mathrm{C}$ for $20 \mathrm{~min}$. After adding $75 \mu \mathrm{L}$ trichloroacetic acid $(10 \% \mathrm{w} / \mathrm{v})$, samples were centrifuged for $10 \mathrm{~min}$ at $1000 \mathrm{~g}$. The supernatants $(75 \mu \mathrm{L})$ were transferred to another microtiter plate and mixed with $75 \mu \mathrm{L}$ distilled water and $15 \mu \mathrm{L}$ iron (III) chloride $(0.1 \%$ $\mathrm{w} / \mathrm{v})$. After reading the absorbance at $700 \mathrm{~nm}$, effective concentrations $\left(\mathrm{EC}_{50}\right)$ were calculated.

\section{Chromosome aberration (CA) assay}

The samples were added to chromosome medium (Chromosome Medium B, Biochrom, Berlin) and final concentrations of $1,5,10,25,50$ and $100 \mathrm{mg} / \mathrm{L}$ of the lichen extracts were added to the medium after $24 \mathrm{~h}$. Cultures were incubated at $37^{\circ} \mathrm{C}$ for $72 \mathrm{~h}$. A negative control (control') and a control ${ }^{+}$(Mitomycin-C $\left(\mathrm{C}_{15} \mathrm{H}_{18} \mathrm{~N}_{4} \mathrm{O}_{5}\right.$, Sigma, St, Louis/MO, USA, at $\left.\left.10^{-7} \mathrm{M}\right)\right)$ were also used. The cells were exposed to colchicine (Sigma, St, Louis/MO, USA) 2 h before harvesting. At the end of the incubation, cells were harvested by centrifugation at $900 \mathrm{rpm}$ for $10 \mathrm{~min}$. Then, the cells were treated with $\mathrm{KCl}$ as hypotonic solution for $15 \mathrm{~min}$ and fixation was performed (methanol:glacial acetic acid 3:1). The cell suspension was centrifuged at $900 \mathrm{rpm}$ for $10 \mathrm{~min}$ after each fixative treatment. After the last fixation process, drops of the fixed cell suspension were dropped on a clean slide and airdried. The slides were stained in 3\% Giemsa solution in phosphate buffer ( $\mathrm{pH} \mathrm{6.8)} \mathrm{for} 15 \mathrm{~min}$. For each treatment, 30 well-spreaded metaphases were analysed to detect the presence of chromosomal aberrations (CA). In order to classify the different types of aberrations, chromatid/chromosome gaps, chromatid/ chromosome breaks and fragments were determined. In addition, the effect of the experiments on cell proliferation was supported by mitotic index (MI) analysis. This analysis was detected by the following equation:

$\mathrm{MI}=($ number of dividing cells/total cell count $) \times 100$.

Micronucleus (MN) assay

In this experiment, similar applications to chromosome protocol were performed. Briefly, the heparinized blood was mixed with chromosome medium (Chromosome Medium B, Merck, Berlin). Five samples of the extracts at different concentrations $(1,5,10,25,50$ and 100 $\mathrm{mg} / \mathrm{L}$ ) were added to cultures $24 \mathrm{~h}$ after the beginning of incubation. In addition, a positive control $(+)$ (Mitomycin-C, $10^{-7} \mathrm{M}$ ) and negative control (-) group with no extract were included to the treatments. $44 \mathrm{~h}$ after the beginning of incubation cytochalasin B (Sigma, St, Louis/MO, USA) was added to the culture tubes. After the fixation process, the cell suspensions were dropped onto clean slides, air-dried and stained with 3\% Giemsa solution. 1000 binuclear cells per concentration were examined for micronucleus (MN) scoring and to determine the number of cells with 1, 2, 3 and 4 nuclei. Nuclear division index (NDI) was calculated using the formula:

$$
\begin{gathered}
\mathrm{NDI}=[(1 \times \mathrm{N} 1)+(2 \times \mathrm{N} 2)+(3 \times \mathrm{N} 3)+(4 \times \mathrm{N} 4)] / \\
\mathrm{n}(\text { total cell count }) .
\end{gathered}
$$

In this formula, N1-N4 represents the number of cells with 1 to 4 nuclei.

Statistical analyses

Different results of the treatments were interpreted using the analysis of variance followed by appropriate post-hoc test (Duncan test) and differences were accepted as statistically significant at $\mathrm{p}<0.05$. Probit regression analysis was used for calculating $\mathrm{EC}_{50}$ and $\mathrm{IC}_{50}$ values. Statistical Package for Social Sciences (SPSS, version 21.0, IBM Corporation, Armonk, NY) software was used for all analyses. 
FARMACIA, 2019, Vol. 67, 5

\section{Results and Discussion}

Identification and quantification of main phenolic compounds by HPLC

HPLC analysis revealed the presence of eleven phenolic compounds (chlorogenic acid, p-coumaric acid, q-coumaric acid, ferulic acid, gallic acid, phlorodizin, protocatechuic acid, resveratrol, rutin, syringic acid and valinic) in PME, PWE, UME and UWE. When the amounts of the phenolic compounds detected in methanol and water extracts were compared, PWE outweighed than PME. UME was in a position equivalent to UWE. When all the compounds were examined, the high amount of rutin in PME, PWE and UME was noteworthy. It is known that rutin is used in many pharmacological experiments because of its potent antioxidant property. Therefore, the high content of this compound in the extracts is of great importance for drug development [24]. Rutin was also used in many lichen-antioxidant studies as standard compound [26]. Another remarkable point was that resveratrol was only detected in PME. As for UWE, it was determined that it was especially rich in chlorogenic and ferulic acid. While q-coumaric acid was not detected in PME and UWE, it was detected in the lowest quantity in PWE and UME. Ferulic and syringic acid were the antioxidants that were present in the lowest amounts in PME and UWE, respectively (Table I). Ristic et al. [21] revealed various antioxidant activities of depsides, dibenzofurane and depsidones identified in Ramalina fraxinea and $R$. fastigiata by HPLC. Similarly, Oran et al. [17] proposed that Usnea fulvoreagens, U. intermedia and $U$. filipendula could be used as antioxidant agents due to their total phenolic components.

Quantities (mg/kg) of different phenolic compounds of the tested lichen

\begin{tabular}{|c|c|c|c|c|}
\hline Phenolic compound & PME & PWE & UME & UWE \\
\hline Chlorogenic acid & $26.31^{\mathrm{c}} \pm 0.14$ & $16.14^{\mathrm{c}} \pm 0.19$ & $360.78^{b c} \pm 2.56$ & $492.86^{\mathrm{a}} \pm 3.21$ \\
\hline p-Coumaric acid & $2.53^{\mathrm{e}} \pm 0.04$ & $4.45^{\mathrm{e}} \pm 0.37$ & $423.81^{b} \pm 2.67$ & $15.09^{\mathrm{e}} \pm 0.21$ \\
\hline q-Coumaric acid & nd & $0.16^{\mathrm{f}} \pm 0.01$ & $0.15^{\mathrm{d}} \pm 0.01$ & nd \\
\hline Ferulic acid & $0.81^{\mathrm{f}} \pm 0.06$ & $0.37^{\mathrm{f}} \pm 0.01$ & $0.34^{\mathrm{d}} \pm 0.01$ & $320.12^{b} \pm 2.98$ \\
\hline Gallic acid & $59.05^{\mathrm{b}} \pm 0.12$ & $96.76^{b} \pm 0.41$ & $51.27^{\mathrm{cd}} \pm 0.86$ & $106.83^{c} \pm 0.87$ \\
\hline Phlorodizin & nd & $1.59^{\mathrm{f}} \pm 0.01$ & nd & $1.97^{\mathrm{f}} \pm 0.01$ \\
\hline Protocatechuic acid & $2.28^{\mathrm{e}} \pm 0.05$ & $14.65^{\mathrm{c}} \pm 0.03$ & $1.42^{\mathrm{d}} \pm 0.21$ & $12.85^{\mathrm{e}} \pm 0.06$ \\
\hline Resveratrol & $2.20^{\mathrm{e}} \pm 0.08$ & nd & nd & nd \\
\hline Rutin & $6667.69^{\mathrm{a}} \pm 11.54$ & $343.36^{\mathrm{a}} \pm 0.64$ & $47676.83^{a} \pm 26.55$ & $41.07^{\mathrm{d}} \pm 0.12$ \\
\hline Syringic acid & $3.69^{\mathrm{d}} \pm 0.06$ & $7.27^{\mathrm{d}} \pm 0.17$ & $1.75^{\mathrm{d}} \pm 0.13$ & $0.56^{\mathrm{f}} \pm 0.01$ \\
\hline Valinic & $0.83^{\mathrm{f}} \pm 0.11$ & $6.82^{\mathrm{de}} \pm 0.42$ & $1.41^{\mathrm{d}} \pm 0.04$ & $0.61^{\mathrm{f}} \pm 0.01$ \\
\hline
\end{tabular}

Each value is expressed as mean \pm standard deviation $(n=3)$; Values followed by different superscript letters in the same column differ significantly at $\mathrm{p}<0.05 ;$ nd: not determined

\section{TAC activity in the cells}

When the effects of the tested extracts on TAC change in cells were examined, a concentration-dependent increase was observed. While the treatments at the lowest concentration $(1 \mathrm{mg} / \mathrm{L})$ of the extracts did not significantly $(p>0.05)$ increase TAC in HPLs compared with control', TAC levels of the cells exposed to high concentrations $(\geq 50 \mathrm{mg} / \mathrm{L}$ ) were close to control $^{+}$. The concentration of $100 \mathrm{mg} / \mathrm{L}$ of PWE attracted the attention as this experiment resulted in the highest TAC level. Furthermore, the concentration of $50 \mathrm{mg} / \mathrm{L}$ of PWE was not statistically significant $(p>0.05)$ from the previous treatment. Although TAC levels of PME and UME were lower compared to PSW, there was significantly $(\mathrm{p}>0.05)$ no difference between concentrations of 50 and 100 $\mathrm{mg} / \mathrm{L}$ of them. The lowest results among the extract tests belonged to UWE (Figure 1a).

TOS activity in the cells

Oxidative stress levels in extract and control groups in HPLs were assessed with TOS. In this assay, control $^{+}$was separated from other experiments by high TOS value (37.49 $\mu \mathrm{mol} \mathrm{H}_{2} \mathrm{O}_{2}$ equivalent/L). In general, it was determined that the extracts did not raise the oxidative stress level in HPLs at a dangerous rate. Furthermore, while both methanol and water extracts did not significantly $(\mathrm{p}>0.05)$ increase TOS level in the cells compared with control ${ }^{-}(12.57 \mu \mathrm{mol}$ $\mathrm{H}_{2} \mathrm{O}_{2}$ equivalent/L), the maximum concentration of PWE (9.86 $\mu \mathrm{mol} \mathrm{H}_{2} \mathrm{O}_{2}$ equivalent/L) and UWE $\left(11.23 \mu \mathrm{mol} \mathrm{H}_{2} \mathrm{O}_{2}\right.$ equivalent/L) statistically $(\mathrm{p}<0.05)$ reduced TOS rate. Besides, it was a remarkable result that the TOS activity caused by the treatment with $50 \mathrm{mg} / \mathrm{L}$ of PWE was not statistically significant ( $\mathrm{p}>$ 0.05 ) from the maximum concentration of UWE (Figure 1b). Other studies concluded that the reducing effect of $\alpha$-glucan obtained from Cladina rangiferina against $\mathrm{Pb}^{2+}$-induced oxidative is of interest and it was revealed that the tested lichen decreased reactive oxygen species (ROS) generation in alveolar epithelium cells [11]. Another study assessed the inhibition of oxidative stress on neurons and astrocytes cells. In this research, it was reported that a secondary metabolite of Cetraria islandica, fumarprotocetraric acid showed a protective role against $\mathrm{H}_{2} \mathrm{O}_{2}$-induced oxidative damage [9]. 

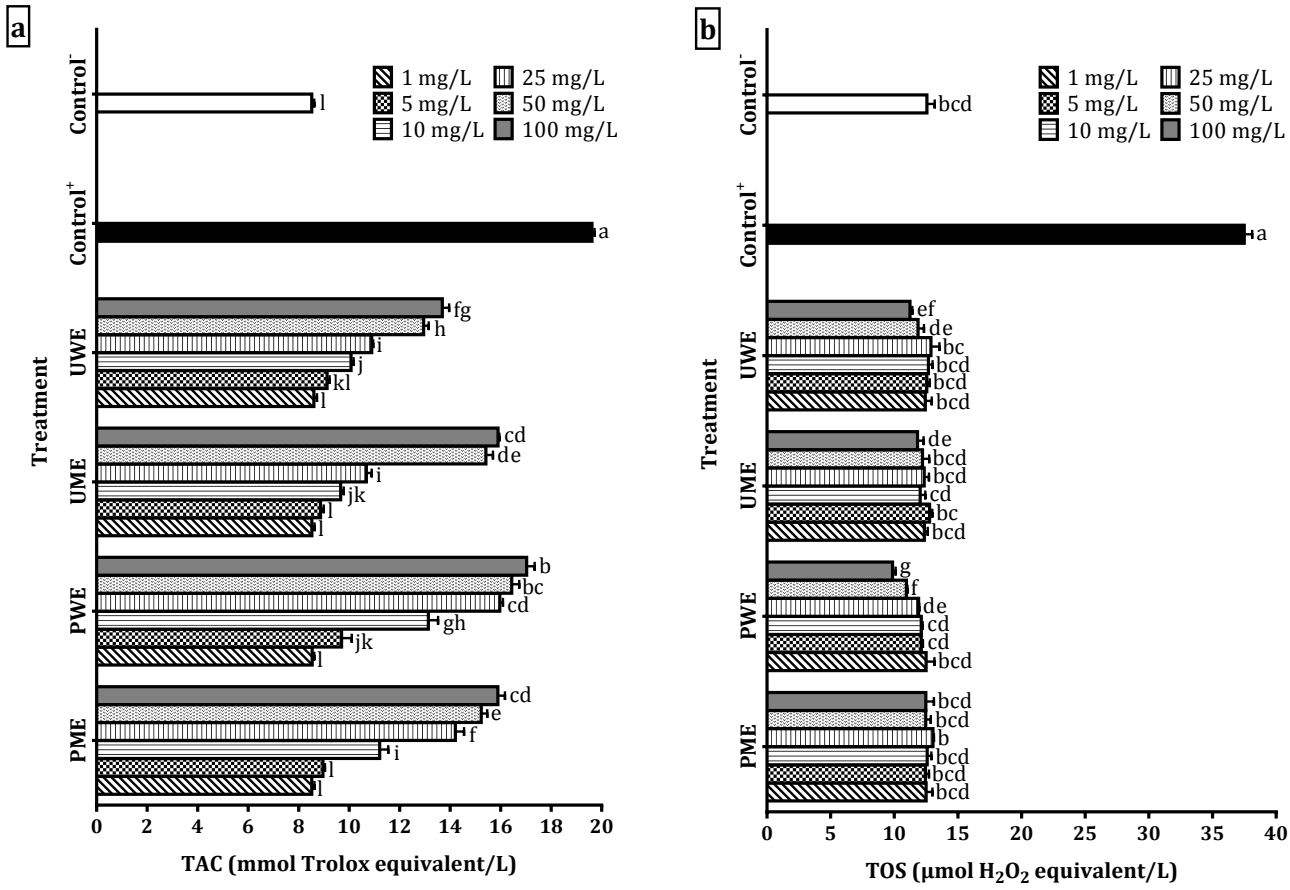

Figure 1.

TAC (a) and TOS (b) levels in the HPLs in the presence of different lichen extracts

Each value represents the mean standard deviation of three experiments. Different small letters indicate significant differences among treatments at $\mathrm{p}<0.05$

\section{Scavenging ability on DPPH radicals}

When investigating the DPPH scavenging activities, increases were registered with increasing concentrations 50 and $100 \mathrm{mg} / \mathrm{L}$ of PWE were noted with activities over $70 \%$. There was also a no statistically $(p>0.05)$ significant difference between these treatments. Another critical extract that contributed to the capture of DPPH radicals was UWE. High concentrations (25 - 100 $\mathrm{mg} / \mathrm{L}$ ) of UWE had 60 - 65\% DPPH scavenging ability. Based on the highest concentrations, the scavenging activities of the extracts on DPPH radicals were in the descending order $\mathrm{PWE}>\mathrm{UWE}>\mathrm{PME}>$ UME (Figure 2a). Based on the $\mathrm{IC}_{50}$ values that helped to bring out the effects on the DPPH radical of the extracts, PWE was found to be effective with the lowest $\mathrm{IC}_{50}$ value $(10.28 \mathrm{mg} / \mathrm{L})$. The highest value belonged to PME with $42.37 \mathrm{mg} / \mathrm{L}$. In addition, it was seen that $\mathrm{IC}_{50}$ values of all extract treatments and gallic acid used as standard antioxidant molecule were statistically $(p<0.05)$ different from each other (Table II).

Table II

$\mathrm{IC}_{50}$ values $(\mathrm{mg} / \mathrm{L})$ of extracts and standard for scavenging on DPPH radicals

\begin{tabular}{ccc}
\hline Treatment & $\mathrm{IC}_{50}$ (limits) & Slope \pm standard error \\
\hline PME & $42.37^{\mathrm{a}}(34.78-53.11)$ & $0.81 \pm 0.05$ \\
$\mathrm{PWE}$ & $10.28^{\mathrm{d}}(8.76-11.97)$ & $0.94 \pm 0.05$ \\
$\mathrm{UME}$ & $37.96^{\mathrm{b}}(32.09-45.75)$ & $0.93 \pm 0.06$ \\
UWE & $28.80^{\mathrm{c}}(24.96-33.55)$ & $1.05 \pm 0.06$ \\
Gallic acid & $0.04^{\mathrm{e}}(0.03-0.05)$ & $0.60 \pm 0.05$ \\
\hline
\end{tabular}

Values followed by different superscript letters in the same column differ significantly at $\mathrm{p}<0.05$

\section{Chelating ability of metal ions}

When focused on metal chelating activities of the tested lichen extracts, it was revealed that there was a correlation between the chelating capacities of the extracts and their concentrations. There were observed close metal chelating activities between PWE and UWE; PME and UME treatments. While concentrations of $25-100 \mathrm{mg} / \mathrm{L}$ of PWE and UWE caused high results (60 - 70\%), in PME and UME, concentrations of 50 and $100 \mathrm{mg} / \mathrm{L}(55-60 \%)$ were remarkable (Figure $2 \mathrm{~b}$ ). Moreover, the $\mathrm{IC}_{50}$ values calculated from the results of the chelating activity showed that the potent inhibitor was PWE $(13.24 \mathrm{mg} / \mathrm{L})$. The standard chelating agent, EDTA possessed the lowest $\mathrm{IC}_{50}$ value among the treatments $(0.16 \mathrm{mg} / \mathrm{L})$. According to $\mathrm{IC}_{50}$ values, the extracts were in the ascending order of PWE $<\mathrm{UWE}<\mathrm{UME}<\mathrm{PME}$ and they were statistically $(\mathrm{p}<0.05)$ different from each other (Table III).

Table III

$\mathrm{IC}_{50}$ values $(\mathrm{mg} / \mathrm{L})$ of extracts and standard for chelating on ferrous ions

\begin{tabular}{ccc}
\hline Treatment & $\mathrm{IC}_{50}$ (limits) & Slope \pm standard error \\
\hline PME & $50.33^{\mathrm{a}}(40.88-64.14)$ & $0.81 \pm 0.05$ \\
PWE & $13.24^{\mathrm{d}}(10.86-16.10)$ & $0.71 \pm 0.05$ \\
$\mathrm{UME}$ & $43.46^{\mathrm{b}}(35.89-54.09)$ & $0.84 \pm 0.05$ \\
UWE & $25.23^{\mathrm{c}}(21.95-29.19)$ & $1.06 \pm 0.06$ \\
EDTA & $0.16^{\mathrm{e}}(0.14-0.18)$ & $1.21 \pm 0.06$ \\
\hline
\end{tabular}


Values followed by different superscript letters in the same column differ significantly at $\mathrm{p}<0.05$

\section{Reducing power activity}

In the experiments testing the reducing power activities of lichen extracts at different concentrations, concentrations of 50 and $100 \mathrm{mg} / \mathrm{L}$ of PWE that were not statistically significant $(p>0.05)$ showing towering activity. The reducing power activity emerging by the trials at high concentration (50 and $100 \mathrm{mg} / \mathrm{L}$ ) of UWE was close to PWE. Additionally, there was no difference $(p>0.05)$ between concentrations of 50 and 100 $\mathrm{mg} / \mathrm{L}$ of PME and UME. Considering the lowest concentrations, it was defined that there was no statistically significant difference between PWE, PME and UME (Figure $2 \mathrm{c}$ ). $\mathrm{EC}_{50}$ values also supported the results in Figure 2c. As shown in Table IV, $\mathrm{EC}_{50}$ values of PME-UME and PWE-UWE were very close. However, $\mathrm{EC}_{50}$ values of the extracts and standard for reducing power were as follows: gallic acid $<\mathrm{PWE}<$ $\mathrm{UWE}<\mathrm{UME}<\mathrm{PME}$.

Table IV

$\mathrm{EC}_{50}$ values $(\mathrm{mg} / \mathrm{L})$ of extracts and standard for reducing power

\begin{tabular}{cc}
\hline Treatment & $\mathrm{EC}_{50}$ \\
\hline PME & $3.52^{\mathrm{a}}$ \\
PWE & $2.81^{\mathrm{d}}$ \\
UME & $3.43^{\mathrm{b}}$ \\
UWE & $2.89^{\mathrm{c}}$ \\
Gallic acid & $0.42^{\mathrm{e}}$
\end{tabular}

Values followed by different superscript letters in the same column differ significantly at $\mathrm{p}<0.05$

a

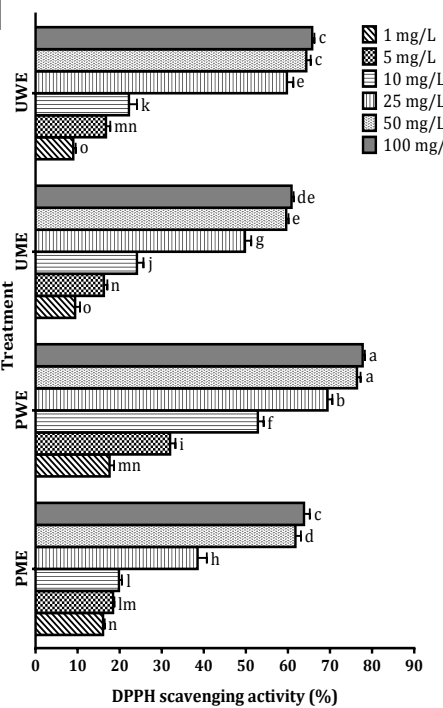

DPPH scavenging activity $(\%)$

DPPH (a) scavenging, metal chelating (b) and reducing power activities (c) of the different lichen extracts Each value represents the mean standard deviation of three experiments. Different small letters indicate significant differences among treatments at $\mathrm{p}<0.05$

As in many herbal product trials, antioxidant substances are at the forefront in the anticancer or therapeutic effect studies $[16,29]$. The results of the experiments showed that anticytotoxic and antigenotoxic potentials of $P$. canina and $U$. nylanderiana on HPLs were attributed to their antioxidative capacities. Leandro et al. [15] contributed to the literature by proving that the chemical agent-induced genotoxicity on hamster lung fibroblast was reduced by (+)-usnic acid, a lichen secondary metabolite. They reported that the antioxidant activity of $(+)$-usnic acid was effective in this regard. Some researchers have determined the total antioxidant capacity-enhancing effects of different lichen species such as Dermatocarpon intestiniforme, Aspicilia calcerea, Cetraria chlorophylla [3], Hypogymnia physodes, Usnea florida and Ramalina polymorpha [27] on lymphocytes due to their antioxidant properties without genotoxic activity.

Genotoxic/CA and MN activities

In order to assess the genotoxic effects of PME, PWE, UME and UWE against HPLs, CA and MN analyses were performed. In CA assays, chromatid/chromosome breaks, gaps and fragments appeared in HPLs were determined (Figure 3a). In these treatments, the highest CA frequency belonged to control ${ }^{+}$with 0.67 . As determined in Figure $4 \mathrm{a}$, the results of $\mathrm{CA}$ in the cells exposed to all of the other lichen extracts except for the maximum concentration of UME did not differ from the control'. Moreover, a concentrationdependent effect was only observed for UME treatment. 


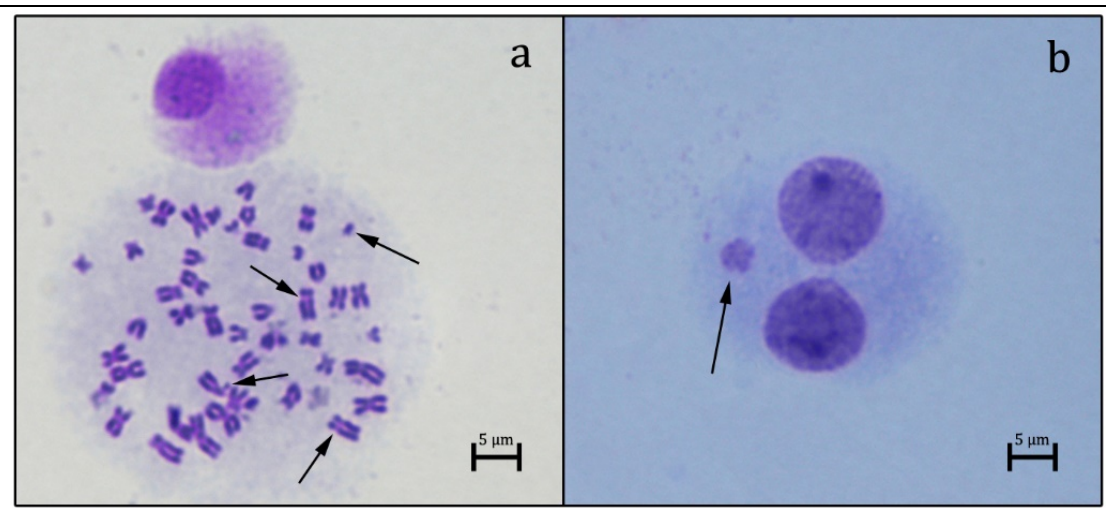

Figure 3.

Images of (a) chromatid/chromosome breaks, gaps, fragments and (b) micronucleated cell that emerge in the experiments $(10 \times 100$ magnification $)$

In the $\mathrm{MN}$ assay, micronucleated cells appearing in HPLs were calculated (Figure 3b). Control $^{+}$markedly had a high $\mathrm{MN}$ ratio (5.81) and this value was statistically $(p<0.05)$ different from all other experiments. It was revealed that UME, UWE and PME statistically $(p<0.05)$ induced the formation of $\mathrm{MN}$ at a concentration of $100 \mathrm{mg} / \mathrm{L}$. Concentrations of 1 $50 \mathrm{mg} / \mathrm{L}$ of the tested extracts did not significantly $(\mathrm{p}>0.05)$ increase $\mathrm{MN}$ frequency compared to control $^{-}(1.87)$ (Figure $4 \mathrm{~b}$ ). Based on the genotoxic effects of $P$. canina and $U$. nylanderiana, CA and $\mathrm{MN}$ tests provided insights about potential effects for genetic damage formation of the tested extracts on

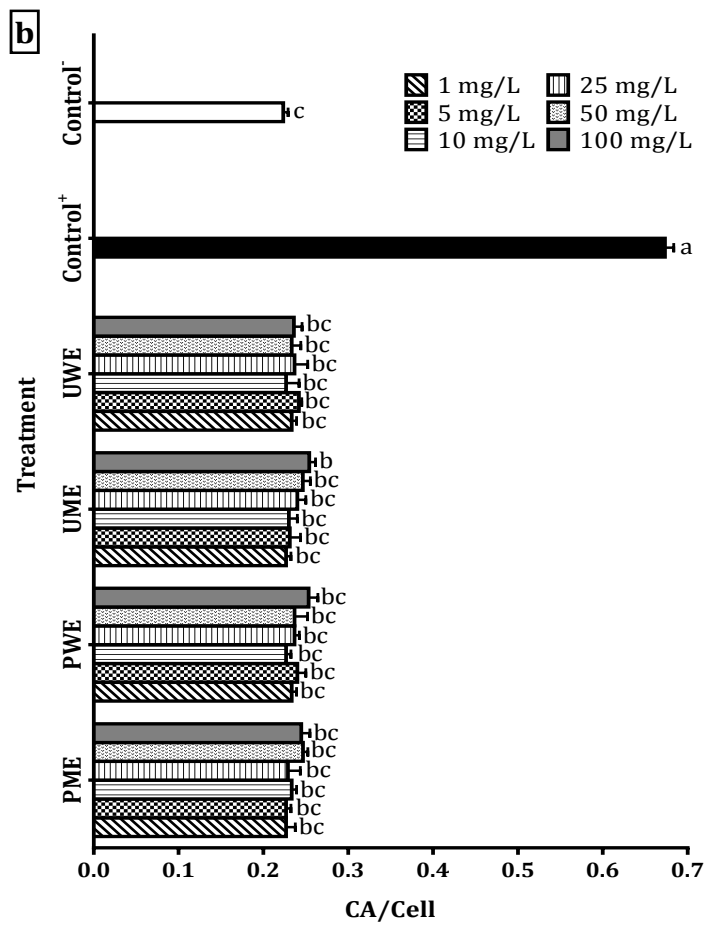

HPLs. To date, the genotoxic effects of many lichen species were discovered by scientists using different methods. Similar to the antigenotoxic part of the present study, Kosanić et al. [13] examined the genotoxic effects of Lasallia pustulata on peripheral blood lymphocytes through MN test and revealed that the frequency of $\mathrm{MN}$ did not significantly change compared with control ${ }^{-}$. In another research, Guterres et al. [10] pronounced that salazinic and psoromic acid isolated from Parmotrema cetratum and Usnea jamaicensis, respectively, significantly decreased by doxorubicin-induced genetic damage against somatic cells of Drosophila melanogaster.

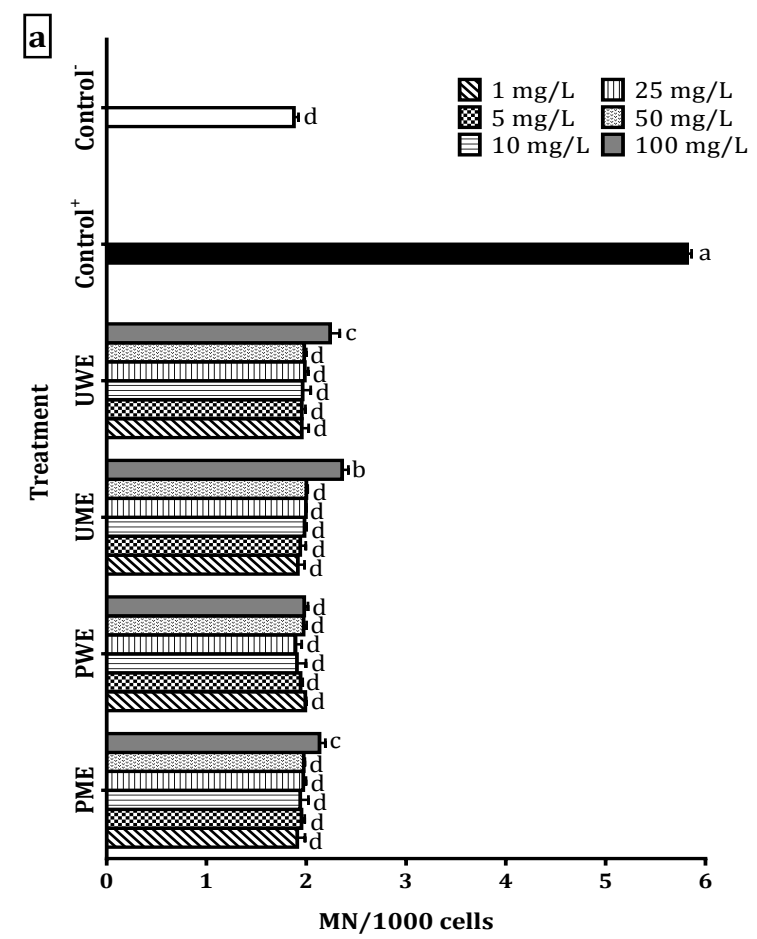

Figure 4.

Frequencies of (a) CA and (b) MN in the HPLs exposed to the different lichen extracts

Each value represents the mean standard deviation of three experiments. Different small letters indicate significant differences among treatments at $\mathrm{p}<0.05$ 
Cytotoxic/MI and NDI activities

MI and NDI determined the effects of PME, PWE, UME and UWE on the proliferation of HPLs. When investigating MI percentage in the HPLs exposed to the lichen extracts, close results were observed. However, it was found that the treatments at the concentration of $100 \mathrm{mg} / \mathrm{L}$ of PME and UME lowered MI. Besides, there was no significant difference between the concentrations of 50 and $100 \mathrm{mg} / \mathrm{L}$ of UME. Other treatments of lichen extracts were not statistically

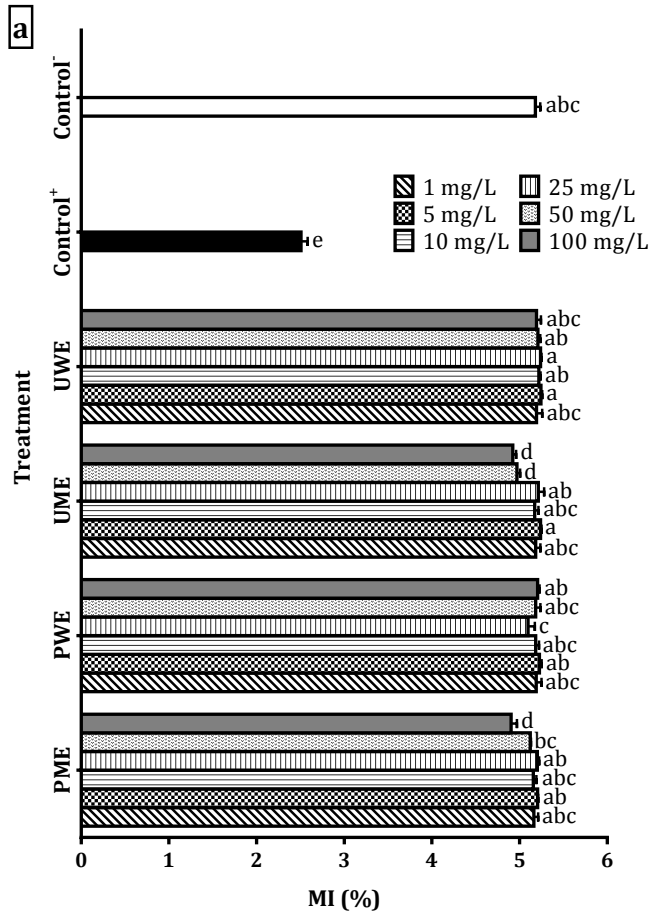

$(\mathrm{p}>0.05)$ different from control $(\mathrm{MI} \%=5.18)$ (Figure 5a).

NDI was calculated based on the nucleus numbers in HPLs (Figure 6). In NDI analyses, the value of control $^{+}$that negatively affected the nuclear division was 1.27 and data of other trials was significantly $(\mathrm{p}<0.05)$ different compared with the previously mentioned value. None of the treatments of the tested extract was statistically $(\mathrm{p}>0.05)$ different from NDI (1.51) of control' (Figure 5b).

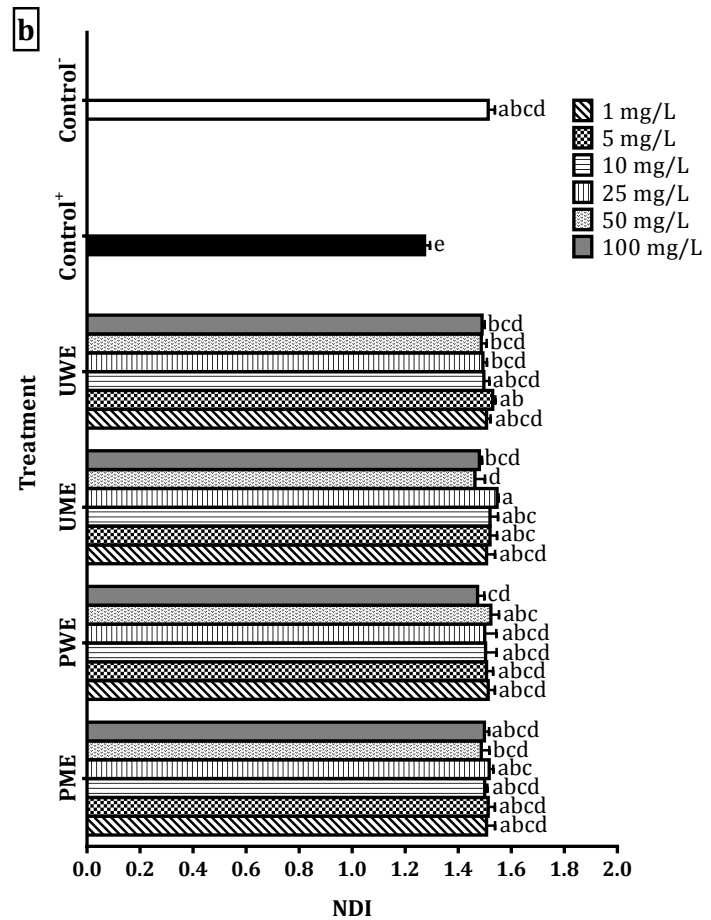

Figure 5.

MI percentage (a) and NDI (b) in the HPLs exposed to different lichen extracts

Each value represents the mean standard deviation of three experiments. Different small letters indicate significant differences among treatments at $\mathrm{p}<0.05$

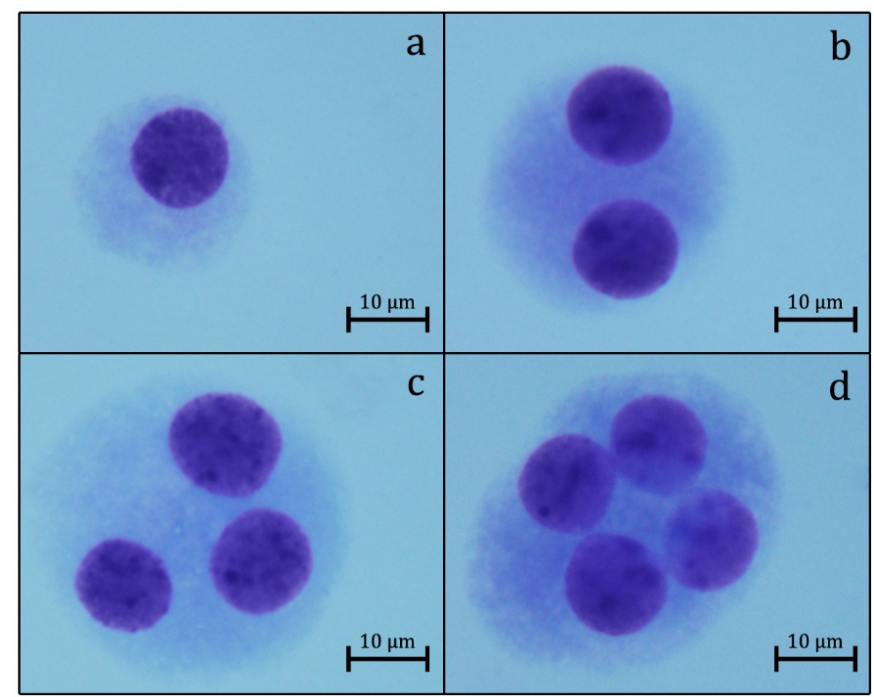

Figure 6.

Images of mononucleated (a), binucleated (b), trinucleated (c) and tetranucleated (d) cells that emerge in the experiments $(10 \times 100$ magnification $)$ 
Information on whether the lichens show cytotoxic properties on different cells is available in the literature. Emsen et al. [8] proved that the viability of human amnion fibroblasts exposed to olivetoric and physodic acid of lichen secondary metabolites, was affected depending on the dose of metabolite. However, they suggested that low concentrations of these metabolites did not significantly indicate cytotoxicity on the fibroblasts. In a different experiment carried out on lymphocytes, it was detected that Cetrelia olivetorum, Cetraria aculeata and Cladonia chlorophaea did not have a significant anti-mutagenic effect [5].

\section{Conclusions}

In conclusion, in the present study, it was revealed that PME, PWE, UME and UWE except for their high concentrations did not show significant cytotoxic, genotoxic and pro-oxidative effects on HPLs. There were correlations between different antioxidant activities of the extracts and TAC levels in HPLs exposed to them. In addition, eleven phenolic compounds identified in the chemical composition of $P$. canina and $U$. nylanderiana by HPLC analysis scientifically reinforce their antioxidant capacities. Taking into account all of the study findings, we can conclude that PME, PWE, UME and UWE applications in specific concentrations (1 - $25 \mathrm{mg} / \mathrm{L})$ may increase TAC in HPLs without cytotoxic and genotoxic effects. PME, UME, UWE and especially PWE from lichen-derived extracts are worth investigating as possible antioxidative agents.

\section{References}

1. Anand David A, Arulmoli R, Parasuraman S, Overviews of biological importance of quercetin: a bioactive flavonoid. Pharmacogn Rev., 2016; 10(20): 84-89.

2. Aschenbrenner IA, Cernava T, Berg G, Grube M, Understanding microbial multi-species symbioses. Front Microbiol., 2016; 7: 1-9.

3. Aydin E, Turkez H, Antioxidant and genotoxicity screening of aqueous extracts of four lichens collected from North East Anatolia. Fresenius Environ Bull., 2011; 20(8A): 2085-2091.

4. Bala A, Mondal C, Haldar PK, Khandelwal B, Oxidative stress in inflammatory cells of patient with rheumatoid arthritis: clinical efficacy of dietary antioxidants. Inflammopharmacology, 2017; 25(6): 595-607.

5. Ceker S, Orhan F, Sezen S, Gulluce M, Ozkan H, Aslan A, Agar G, Anti-mutagenic and anti-oxidant potencies of Cetraria aculeata (Schreb.) Fr., Cladonia chlorophaea (Flörke ex sommerf.) spreng. and Cetrelia olivetorum (Nyl.) W.L. Culb. \& C.F. Culb.). Iran J Pharm Res., 2018; 17(1): 326-335.

6. Demir L, Togar B, Turkez H, Sozio P, Aslan A, Stefano ADi, The investigation of cytogenetic and oxidative effects of diffractaic acid on human lymphocyte cultures. Brazilian Arch Biol Technol., 2015; 58(1): 75-81.

7. Emsen B, Aslan A, Use of lichens as natural insecticide. Anatol J Bot., 2018; 2(1): 22-27.

8. Emsen B, Turkez H, Togar B, Aslan A, Evaluation of antioxidant and cytotoxic effects of olivetoric and physodic acid in cultured human amnion fibroblasts. Hum Exp Toxicol., 2017; 36(4): 376-385.

9. Fernández-Moriano C, Divakar PK, Crespo A, Gómez-Serranillos MP, In vitro neuroprotective potential of lichen metabolite fumarprotocetraric acid via intracellular redox modulation. Toxicol Appl Pharmacol., 2017; 316: 83-94.

10. Guterres ZDR, Honda NK, Coelho RG, Alcantara GB, Micheletti AC, Antigenotoxicity of depsidones isolated from Brazilian lichens. Orbital., 2017; 9(1): 50-54.

11. Huang X, Ma J, Wei L, Song J, Li C, Yang H, Du Y, Gao T, Bi H, An antioxidant $\alpha$-glucan from Cladina rangiferina (L.) Nyl. and its protective effect on alveolar epithelial cells from $\mathrm{Pb}^{2+}$-induced oxidative damage. Int J Biol Macromol., 2018; 112: 101-109.

12. Karatas M, Dogan M, Emsen B, Aasim M, Determination of in vitro free radical scavenging activities of various extracts from in vitro propagated Ceratophyllum demersum L. Fresenius Environ Bull., 2015; 24(9a): 2946-2952.

13. Kosanić M, Ranković B, Stanojković T, Stošić I, Grujičić D, Milošević-Djordjević O, Lasallia pustulata lichen as possible natural antigenotoxic, antioxidant, antimicrobial and anticancer agent. Cytotechnology, 2016; 68(4): 999-1008.

14. Kumar A, Suryadevara N, Hill TM, Bezbradica JS, Van Kaer L, Joyce S, Natural killer T cells: an ecological evolutionary developmental biology perspective. Front Immunol., 2017; 8: 1-19.

15. Leandro LF, Munari CC, Sato VLFL, Alves JM, de Oliveira PF, Mastrocola DFP, Martins S de PL, Moraes T da S, de Oliveira AI, Tozatti MG, Cunha WR, Tavares DC, Assessment of the genotoxicity and antigenotoxicity of (+)-usnic acid in V79 cells and Swiss mice by the micronucleus and comet assays. Mutat Res., 2013; 753(2): 101-106.

16. Legouin B, Lohézic-Le Dévéhat F, Ferron S, Rouaud I, Le Pogam P, Cornevin L, Bertrand M, Boustie J, Specialized metabolites of the lichen Vulpicida pinastri act as photoprotective agents. Molecules, 2017; 22(7): 1-17.

17. Oran S, Sahin S, Sahinturk P, Ozturk S, Demir C, Antioxidant and antimicrobial potential, and HPLC analysis of stictic and usnic acids of three Usnea species from Uludag mountain (Bursa, Turkey). Iran J Pharm Res., 2016; 15(2): 527-535.

18. Pisoschi AM, Pop A, The role of antioxidants in the chemistry of oxidative stress: a review. Eur J Med Chem., 2015; 97: 55-74.

19. Pol CS, Savale SA, Khare R, Verma N, Behera BC, Antioxidative, cardioprotective, and anticancer potential of two lichenized fungi, Everniastrum cirrhatum and Parmotrema reticulatum, from Western Ghats of India. J Herbs Spices Med Plants., 2017; 23(2): 142-156.

20. Purvis OW, Coppins BJ, Hawksworth DL, James PW, Moore DM, The lichen flora of Great Britain 
and Ireland. Natural History Museum Publications in Association with the British Lichen Society, 2007, London.

21. Ristic S, Rankovic B, Kosanić M, Stamenkovic S, Stanojković T, Sovrlić M, Biopharmaceutical potential of two Ramalina lichens and their metabolites. Curr Pharm Biotechnol., 2016; 17(7): 651-658.

22. Rodríguez-Delgado MA, Malovaná S, Pérez JP, Borges T, García Montelongo FJ, Separation of phenolic compounds by high-performance liquid chromatography with absorbance and fluorimetric detection. J Chromatogr A., 2001; 912(2): 249-257.

23. Santos PC, Teixeira MM, Souza DG, Opportunities for the development of novel therapies based on host-microbial interactions. Pharmacol Res., 2016; 112: 68-83.

24. Sharma S, Ali A, Ali J, Sahni JK, Baboota S, Rutin: therapeutic potential and recent advances in drug delivery. Exp Opin Investig Drugs., 2013; 22(8): 1063-1079.
25. Srinivasan K, Antioxidant potential of spices and their active constituents. Crit Rev Food Sci Nutr., 2014; 54(3): 352-372.

26. Thadhani VM, Choudhary MI, Ali S, Omar I, Siddique H, Karunaratne V, Antioxidant activity of some lichen metabolites. Nat Prod Res., 2011; 25(19): 1827-1837.

27. Turkez H, Aydin E, Aslan A, Effects of lichenic extracts (Hypogymnia physodes, Ramalina polymorpha and Usnea florida) on human blood cells: cytogenetic and biochemical study. Iran J Pharm Res., 2012; 11(3): 889-896.

28. Wirth V, Die flechten baden württembergs. Ulmer, 2008, Stuttgart.

29. Yeash EA, Letwin L, Malek L, Suntres Z, Knudsen K, Christopher LP, Biological activities of undescribed North American lichen species. J Sci Food Agric., 2017; 97(14): 4721-4726. 